\title{
The Effects of Social Media Marketing on Online Consumer Behavior
}

\author{
Simona Vinerean ${ }^{1}$, Iuliana Cetina ${ }^{1}$, Luigi Dumitrescu ${ }^{2} \&$ Mihai Tichindelean ${ }^{1}$ \\ ${ }^{1}$ The Bucharest University of Economics Studies, Romania \\ ${ }^{2}$ Faculty of Economic Sciences, Lucian Blaga University, Sibiu, Romania \\ Correspondence: Simona Vinerean, The Bucharest University of Economics Studies, Romania. Tel: \\ 40-744-563-510. E-mail: simonavinerean@gmail.com
}

Received: March 4, 2013 Accepted: May 20, 2013 Online Published: June 18, 2013

doi:10.5539/ijbm.v8n14p66 URL: http://dx.doi.org/10.5539/ijbm.v8n14p66

\begin{abstract}
Social media allows customers and prospects to communicate directly to your brand representative or about your brand with their friends. However, the obvious question is: who are the people interacting online and how engaged are they in online activities? This paper aims to answer this question based on a study regarding the online activities of 236 social media users, by identifying different types of users, a segmentation of these users and a linear model to examine how different predictors related to social networking sites have a positive impact on the respondents' perception of online advertisements. The answer can help discover how to engage with different types of audiences in order to maximize the effect of the online marketing strategy.
\end{abstract}

Keywords: social media marketing, online consumer behavior, online segmentation, modeling online activities

\section{Introduction}

The Internet and especially social media have changed how consumers and marketers communicate. The Internet has distinct characteristics (Peterson et al., 1997), such as:

- The ability to inexpensively store vast amounts of information at different virtual locations

- The availability of powerful and inexpensive means of searching, organizing, and disseminating such information

- Interactivity and the ability to provide information on demand

- The ability to serve as a transaction medium

- $\quad$ The ability to serve as a physical distribution medium for certain goods (e.g. software)

- Relatively low entry and establishment costs for sellers.

One of the advantages of internet is that it enables businesses to reach a worldwide customer population, so that customers can survey, select, and purchase products and services from businesses around the world (Al Kailani \& Kumar, 2011).

In particular, peer communication through social media, a new form of consumer socialization, has profound impacts on consumer decision making and thus marketing strategies.

Consumer socialization theory predicts that communication among consumers affects their cognitive, affective, and behavioral attitudes (Ward, 1974).

Social media, especially social networking sites, provide a virtual space for people to communicate through the Internet, which also might be an important agent of consumer socialization.

With this research we provide insights to the social media literature and online consumer behavior, in general, and online socializing and interacting activities users engage with on a virtual platform, which are interesting for both academics and online marketing practitioners.

This paper provides a literature review of the evolution of social media marketing and segmentation of social media users from proeminent papers, and continues with a primary research. The aim of this research is to empirically investigate what type of social media users appreciate and have a positive outlook regarding advertising on social networking websites. Particularly, we consider a segmentation of social media users regarding their perceived importance of using social media, and these social media users represent students of 
"Lucian Blaga" University of Sibiu, Romania. The responses that will be further explored were gathered through field research, namely the information was collected directly from respondents via the internet, from September 17 to November 18, 2011. Finally, in the last section of the paper, we provide the contributions of the research, the managerial implications, and limitations of the research.

\section{Literature Review}

\subsection{The Development of Social Media Marketing}

In recent years, social networking sites and social media have increased in popularity, at a global level. For instance, Facebook is said to have more than a billion active users (as of 2012) since its beginning in 2004 (www.facebook.com). Social networking sites can be described as networks of friends for social or professional interactions (Trusov, Bucklin, \& Pauwels, 2009). Indeed, online social networks have profoundly changed the propagation of information by making it incredibly easy to share and digest information on the internet (Akrimi \& Khemakhem, 2012).

The unique aspects of social media and its immense popularity have revolutionized marketing practices such as advertising and promotion (Hanna, Rohm, \& Crittenden, 2011). Social media has also influenced consumer behavior from information acquisition to post-purchase behavior such as dissatisfaction statements or behaviors (Mangold \& Faulds, 2009) and patterns of Internet usage (Ross et al., 2009; Laroche et al., 2012).

Social media is "a group of internet based applications that builds on the ideological and technological foundations of Web 2.0, and it allows the creation and exchange of user-generated content" (Kaplan \& Haenlein, 2010, p.61). Social media has many advantages as it helps connect businesses to consumers, develop relationships and foster those relationships in a timely manner and at a low cost as Kaplan and Haenlein discovered (2010).

Other functions of social media involve affecting and influencing perceptions, attitudes and end behavior (Williams \& Cothrell, 2000), while bringing together different like-minded people (Hagel \& Armstrong, 1997). In an online environment, Laroche (2012) pointed out that people like the idea of contributing, creating, and joining communities to fulfill needs of belongingness, being socially connected and recognized or simply enjoying interactions with other like-minded members.

The much higher level of efficiency of social media compared to other traditional communication channels prompted industry leaders to state that companies must participate in Facebook, Twitter, MySpace, and others, in order to succeed in online environments (Kaplan \& Haenlein, 2010; Laroche et.al. 2012). Thus, more industries try to benefit from social media as they can be used to develop strategy, accept their roles in managing others' strategy or follow others' directions (Williams \& Williams, 2008).

Social media websites provide an opportunity for companies to engage and interact with potential and current consumers, to encourage an increased sense of intimacy of the customer relationship, and build all important meaningful relationships with consumers (Mersey, Malthouse, \& Calder 2010) especially in today's business environment when consumer loyalty can vanish at the smallest mistake, which can additionally have online propagation of their unfortunate encounter with a particular product, service, brand or company.

Some companies are beginning to take notice of the power of social media. A few corporate social networking websites already allow consumers to not only exchange information about products or services, but also engage in co-creating value in online experiences with offline outcomes, with both current and potential consumers.

\subsection{Segmentation of Social Media Users}

Following the general idea that segmentation can leverage a better understanding of consumers' behavior, and therefore a better targeting, in order to obtain the desired effect of any marketing activity, several studies have been employed to achieve a segmentation of consumers who interact online, particularly to examine their online shopping behavior.

Vellido et al. (1999) investigated consumers' opinion on online purchasing and online vendors that seem to consist of the underlying dimensions "control and convenience," "trust and security," "affordability," "ease of use," and "effort/responsiveness." Using these dimensions as a segmentation base discerns seven segments: "unconvinced," "security conscious," "undecided," “convinced," “complexity avoiders," "cost conscious," and "customer service wary."

Starting from consumers' motivations to use the Internet, McDonald (1996) segmented the Internet audience as "avid adventurers," "fact collectors," "entertainment seekers," and "social shoppers."

Also, Brengman et al. (2005) performed a cluster analysis based on seven factors, such as "Internet convenience", 
"perceived self-inefficacy", "Internet logistics", “Internet distrust”, “Internet offer”, "Internet window-shopping".

\section{Research Method}

\subsection{Research Context}

The present research starts with the problem definition, and in this case, it refers to a detailed understanding of the customer's perception and customs regarding the usage of social media, namely how the students of "Lucian Blaga" University of Sibiu engage on social networking sites.

Furthermore, the main purpose, the objectives and the hypotheses were established, as follows:

- The main purpose: Determining the students' underlying characteristics in terms of social media engagement.

- Objective 1: Determining different types of respondents, based on their online activities.

- Hypothesis 1: At least three types of different users of social media will be identified.

- Objective 2: Determining different segments of respondents.

- Hypothesis 2: At least three clusters of different users of social media will be identified.

- Objective 3: Develop a linear model for studying the impact upon positive reaction to online advertisements

- Hypothesis 3: Social media user classification has a great impact in forming a favorable opinion for online ads.

\subsection{Measurement and Research Instrument}

Data collection was achieved by using an online consumer survey. The data was collected with an online survey targeted at the students of Lucian Blaga University of Sibiu studying for a Bachelor, Master or Ph.D. Degree. A short description of the survey and a link-address was posted on the discussion board of the University's website.

All measurement items were newly formed and were aimed at studying students' behavior and reactions on social media websites in order to provide a better understanding of their interactions in an online environment. Table 1 provides the psychometric properties of the measures.

Considering the fact that the scale items were newly compiled, we measured the reliability of the scales used to evaluate the internal consistency of the constructs. Reliability is identified by Cronbach's alpha with a minimum of 0.70 (Cronbach, 1970; Nunnally, 1978).

Table 1. Reliability statistics for the construct measures

\begin{tabular}{|c|c|c|c|}
\hline Dimension & Scale items & Measurement of scale & $\begin{array}{l}\text { Cronbach's } \\
\text { Alpha for the } \\
\text { scale }\end{array}$ \\
\hline \multirow{9}{*}{$\begin{array}{l}\text { General social } \\
\text { media activities }\end{array}$} & Voting on various sites & \multirow{9}{*}{ 1:_:__:_:_:__:__: } & \multirow[t]{9}{*}{.790} \\
\hline & $\begin{array}{l}\text { Adding labels or tags to photos online (on } \\
\text { Facebook) }\end{array}$ & & \\
\hline & $\begin{array}{l}\text { Contributing to online forums and } \\
\text { discussion groups }\end{array}$ & & \\
\hline & Using the RSS feeds service & & \\
\hline & Contributing or editing wiki articles & & \\
\hline & $\begin{array}{l}\text { Posting of reviews and rating on various } \\
\text { products/ services }\end{array}$ & & \\
\hline & Adding comments to various blog posts & & \\
\hline & $\begin{array}{l}\text { Adding comments to other people's social } \\
\text { media profiles }\end{array}$ & & \\
\hline & Uploading videos on YouTube, Vimeo, etc. & & \\
\hline
\end{tabular}




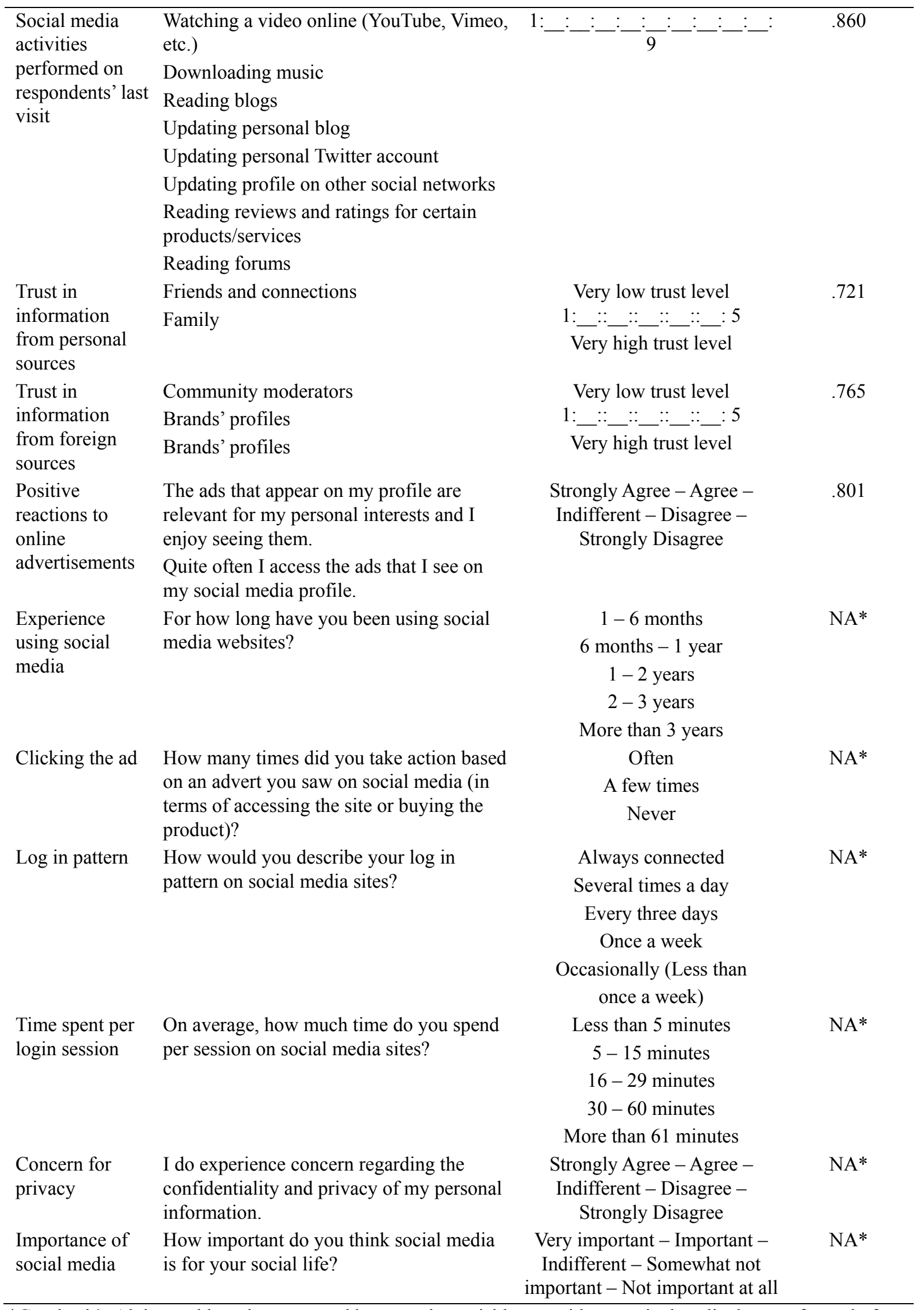

*Cronbach's Alpha could not be computed because the variables are either nominal, ordinal or are formed of one single interval scale. 


\subsection{Data Collection and Sampling}

This study implied a primary research which involved getting original data by conducting a field research. In this case, the information was collected directly from respondents via the internet, from September 17 to November 18, 2011, and the data analysis is quantitative (Dumitrescu, Stanciu, Tichindelean, \& Vinerean, 2012).

Also, this paper is based on an exploratory research whose primary objective is to provide insights into a marketing phenomenon, namely students' pattern of using social media and social networking sites, and particularly in relation to their reaction to advertising in a medium where they decide and choose the information they engage with. The responses were collected from students from "Lucian Blaga" University of Sibiu, a higher education institution in Romania (Dumitrescu, Stanciu, Tichindelean, \& Vinerean, 2012).

As a sampling technique, we used the convenience sampling technique which implies a non-probability sampling. The sample size was represented by students of the "Lucian Blaga" University of Sibiu, Romania in the following proportions: $26.69 \%$ (Bachelor degree, first year of study), 18.22\% (Bachelor degree, second year of study), 31.36\% (Bachelor degree, third year of study), 7.2\% (Master degree, first year of study), $15.25 \%$ (Master degree, second year of study), $0.42 \%$ (Ph.D. degree, first year of study) and $0.85 \%$ (Ph.D. degree, second year of study) (Dumitrescu, Tichindelean, \& Vinerean, 2012; Dumitrescu, Stanciu, Tichindelean, \& Vinerean, 2012).

The sample size was computed by the formula $n=z^{2} *_{s}{ }^{2} / e^{2}$, where $\mathrm{z}$ is a known tabular value for a specific level of significance, $s$ represents the sample standard deviation of the selection variable (number of students by their year of study and study cycle) and e is the standard error. A confidence level of $95 \%$ was chosen, therefore the $\mathrm{z}_{0.95}$ is 1.96 and the sample standard deviation is $\mathrm{s}=28.65$ students by their year of study and study cycle. The chosen sampling standard error is $\mathrm{e}=3.66$ students by their year of study and study cycle. By applying the formula, we have determined a sample size of $\mathrm{n}=235.51=236$ students. The sampling process was executed by applying an online questionnaire to 236 students (Dumitrescu, Tichindelean, \& Vinerean, 2012; Dumitrescu, Stanciu, Tichindelean, \& Vinerean, 2012).

\section{Results}

\subsection{Factor Analysis}

In the data analysis phase of the research, the data was collected via the Internet (FreeOnlineSurveys), and for the information's preparation and processing the researchers used the statistical analysis program SPSS (IBM SPSS, 2011) and firstly the Factor Analysis method.

Factor analysis represents a class of procedures primarily used for data reduction and summarization by identifying the latent variables. A factor is an underlying dimension that explains the correlations among a set of variables. As an extraction method, the researchers used the Principal Components method. In second step, the factors are rotated to ease interpretation. Varimax is the rotation method used most frequently with survey data, because it is a method of orthogonal rotation, which tries to load a smaller number of variables highly onto each factor resulting in a more interpretable and more relevant factors (Field, 2005, pp.630-636). As a clustering criterion, the Schwartz's Bayesian Criterion (BIC) was used.

Additionally, we used the Kaiser-Meyer-Olkin Measure of Sampling Adequacy (KMO) in order to examine the appropriateness of factor analysis. High values (between 0.5 and 1.0) indicate that the factor is relevant.

Table 2. Total variance explained for factor analysis

\begin{tabular}{|c|c|c|c|c|c|c|c|c|c|c|}
\hline \multirow{2}{*}{ Factor } & \multicolumn{3}{|c|}{ Initial Eigenvalues } & \multicolumn{3}{|c|}{$\begin{array}{c}\text { Extraction Sums of Squared } \\
\text { Loadings }\end{array}$} & \multicolumn{3}{|c|}{$\begin{array}{c}\text { Rotation Sums of Squared } \\
\text { Loadings }\end{array}$} & \multirow[t]{2}{*}{$\mathrm{KMO}$} \\
\hline & Total & $\begin{array}{c}\% \text { of } \\
\text { Variance }\end{array}$ & Cumulative $\%$ & Total & $\begin{array}{c}\% \text { of } \\
\text { Variance }\end{array}$ & Cumulative \% & Total & $\begin{array}{c}\text { \% of } \\
\text { Variance }\end{array}$ & Cumulative $\%$ & \\
\hline 1 & 6.338 & 37.284 & 37.284 & 6.338 & 37.284 & 37.284 & 3.140 & 18.468 & 18.468 & .884 \\
\hline 2 & 1.603 & 9.431 & 46.715 & 1.603 & 9.431 & 46.715 & 3.129 & 18.405 & 36.874 & \\
\hline 3 & 1.266 & 7.446 & 54.161 & 1.266 & 7.446 & 54.161 & 2.600 & 15.292 & 52.166 & \\
\hline 4 & 1.041 & 6.122 & 60.283 & 1.041 & 6.122 & 60.283 & 1.380 & 8.117 & 60.283 & \\
\hline $5^{\mathrm{a}}$ & .972 & 5.717 & 66.000 & & & & & & & \\
\hline $6^{\mathrm{a}}$ & .771 & 4.534 & 70.533 & & & & & & & \\
\hline
\end{tabular}




\begin{tabular}{llll}
\hline $7^{\mathrm{a}}$ & .672 & 3.951 & 74.485 \\
$8^{\mathrm{a}}$ & .661 & 3.888 & 78.372 \\
$9^{\mathrm{a}}$ & .635 & 3.733 & 82.105 \\
$10^{\mathrm{a}}$ & .580 & 3.410 & 85.515 \\
$11^{\mathrm{a}}$ & .455 & 2.679 & 88.195 \\
$12^{\mathrm{a}}$ & .417 & 2.454 & 90.649 \\
$13^{\mathrm{a}}$ & .371 & 2.184 & 92.833 \\
$14^{\mathrm{a}}$ & .363 & 2.137 & 94.970 \\
$15^{\mathrm{a}}$ & .327 & 1.921 & 96.892 \\
$16^{\mathrm{a}}$ & .274 & 1.613 & 98.505 \\
$17^{\mathrm{a}}$ & .254 & 1.495 & 100.000
\end{tabular}

${ }^{\mathrm{a}}$ These factors are redundant.

Table 3. Rotated component matrix of the newly formed factors

\begin{tabular}{|c|c|c|c|c|}
\hline & \multicolumn{4}{|c|}{ Factors } \\
\hline & $\begin{array}{l}\text { F1 - Expressers } \\
\text { and Informers }\end{array}$ & $\begin{array}{c}\text { F2 - } \\
\text { Engagers }\end{array}$ & $\begin{array}{c}\text { F3 - } \\
\text { Networkers }\end{array}$ & $\begin{array}{l}\text { F4 - Watchers and } \\
\text { Listeners }\end{array}$ \\
\hline Watching a video online (YouTube, Vimeo, etc.) & .025 & .023 & .239 & .772 \\
\hline Downloading music & .127 & .153 & -.038 & .790 \\
\hline Reading blogs & .385 & .523 & .149 & -.044 \\
\hline Updating personal blog & .703 & .198 & .170 & .060 \\
\hline Updating personal Twitter account & .769 & .048 & .134 & -.012 \\
\hline Updating profile on other social networks & .103 & .097 & .767 & .095 \\
\hline $\begin{array}{l}\text { Reading reviews and ratings for certain } \\
\text { products/services }\end{array}$ & 149 & .751 & .231 & .078 \\
\hline Reading forums & .135 & .823 & -.024 & .257 \\
\hline Voting on various sites & .243 & .533 & .467 & -.062 \\
\hline $\begin{array}{l}\text { Adding labels or tags to photos online (on } \\
\text { Facebook) }\end{array}$ & 190 & 268 & .772 & .040 \\
\hline $\begin{array}{l}\text { Contributing to online forums and discussion } \\
\text { groups }\end{array}$ & .364 & .621 & .246 & .108 \\
\hline Using the RSS feeds service & .698 & .303 & .090 & .069 \\
\hline Contributing or editing wiki articles & .631 & .371 & -.036 & .070 \\
\hline $\begin{array}{l}\text { Posting of reviews and rating on various } \\
\text { products/ services }\end{array}$ & .447 & .559 & .230 & .012 \\
\hline Adding comments to various blog posts & .478 & .462 & .358 & -.005 \\
\hline $\begin{array}{l}\text { Adding comments to other people's social media } \\
\text { profiles }\end{array}$ & 148 & .125 & .845 & 122 \\
\hline Uploading videos on YouTube, Vimeo, etc & .526 & 167 & 228 & .175 \\
\hline
\end{tabular}

After undergoing the Factor Analysis, using the Principal Component Analysis and the Varimax Rotation Method with Kaiser Normalization, four factors emerged. These four factors represent the basis for an understanding of the students' activities on social media sites (Table 3).

The respondents that formed the first factor have been named Expressers and Informers. They get involved in 
the online environment but they are mostly focused on them, on providing information about themselves through blogging, Twitter and uploading wiki articles. However, Expressers and Informers are individuals who stay current, particularly by using the RSS, and then by staying current with different sources of information.

The second factor is entitled Engagers because they seek and read different forums and reviews, but they also get involved by posting comments and reviews, rate sites, products and services. They always what to know more, but they also want to let others know about their opinions regarding different subjects.

The third factor has been entitled Networkers or Socializers because they are particularly involved in social media sites like Facebook, Myspace. The Networkers are very vocal and engage in actions like updating their profiles regularly, posting comments to their friends and tagging pictures.

The final factor has been named Watchers and Listeners because it consists of internet users who have a minimum activity online. They only choose to engage in online activity that are entertainment-driven, namely watching movies, TV shows, videos, listening to music, and download music or video.

Similarly, factor analysis (using the principal components and varimax rotation methods) was also performed for other variables (Table1., namely "Trust in information from personal sources", "Trust in information from foreign sources", "Positive reactions to online advertisements") included in the survey in order to observe the students' underlying attitude regarding reactions to online ads and trust in information provided on social media websites. Three new factors were obtained and the general information about these new variables is presented in Table 4.

Table 4. Information regarding three new factors: positive reactions to online ads, trust in information from personal sources, and trust in information from foreign sources

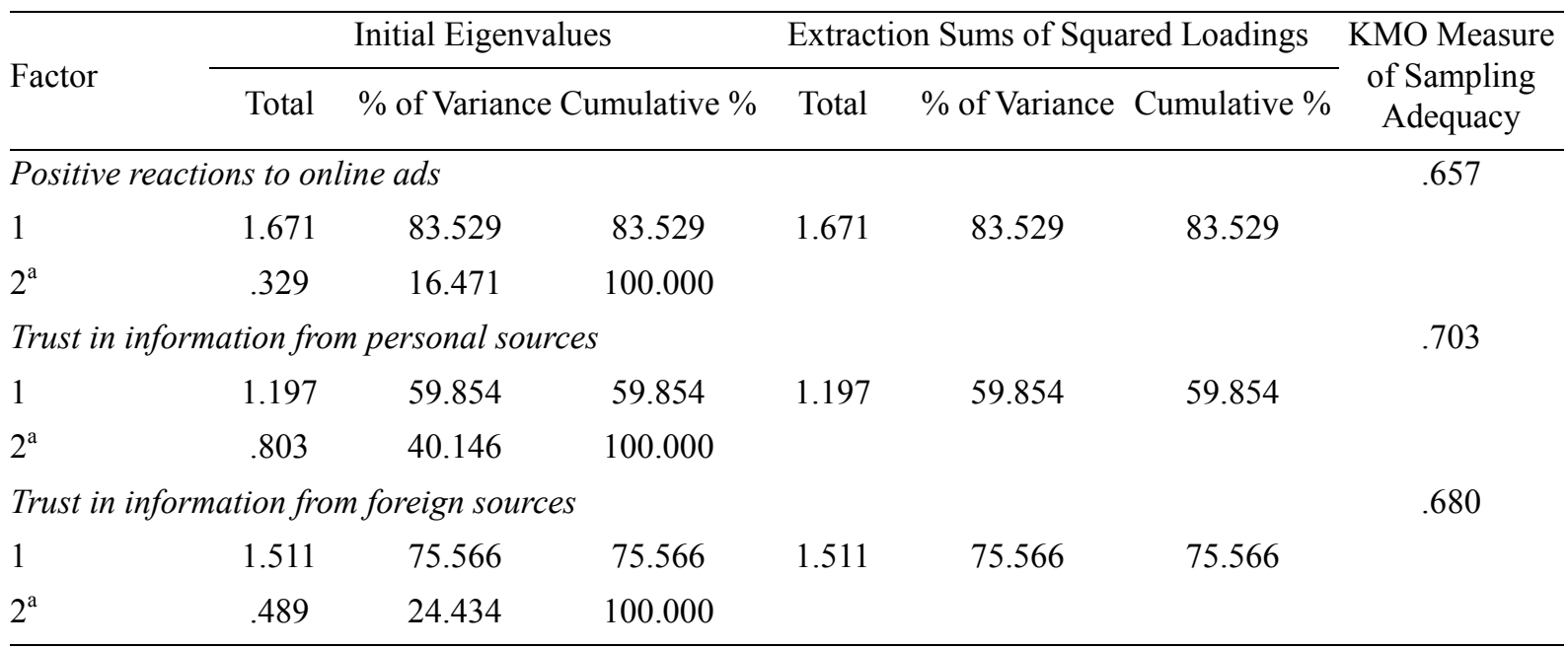

${ }^{\mathrm{a}}$ These factors are redundant.

\subsection{Cluster Analysis}

The next stage involved using the TwoStep Cluster method in order to obtain segmentation, based on newly created factors. Clustering, or segmentation, is used in order to explore patterns of similarity or dissimilarity in different types of participants, i.e. to discover and describe groups of participants who may view particular forms of behavior in similar ways when considering different dimensions, which, eventually, concur to the quality of the higher education institution, "Lucian Blaga" University of Sibiu. We used the Two-Step Cluster procedure in SPSS (IBM SPSS, 2011), which incorporates statistical criteria to determine the optimal number of clusters, considering the number of observations from this database.

Also, the method allowed us to incorporate both continuous (the newly formed factors and the scales presented Table 3 and 4), and categorical variable (also, presented in Table 1). The results of the clustering procedure are presented in Table 5 . 
Table 5. Information that differentiate the clusters formed

\begin{tabular}{|c|c|c|c|}
\hline Variables & $\begin{array}{l}\text { Cluster } 1-36.9 \% \\
\text { ( } 87 \text { respondents) }\end{array}$ & $\begin{array}{l}\text { Cluster } 2-32.2 \% \\
\text { (76 respondents) }\end{array}$ & $\begin{array}{l}\text { Cluster } 3-30.9 \% \\
\text { (73 respondents) }\end{array}$ \\
\hline Clicking the ad & $\begin{array}{l}\text { Most frequent response: } \\
\text { Often }-89.7 \%\end{array}$ & $\begin{array}{l}\text { Most frequent response: } \\
\text { A few times }-77.6 \%\end{array}$ & $\begin{array}{l}\text { Most frequent response: } \\
\text { A few times }-76.7 \%\end{array}$ \\
\hline $\begin{array}{l}\text { Experience using } \\
\text { social media }\end{array}$ & $\begin{array}{l}\text { Most frequent response: } \\
\text { More than } 3 \text { years }-41.4 \%\end{array}$ & $\begin{array}{l}\text { Most frequent response: } \\
2-3 \text { years }-55.3 \%\end{array}$ & $\begin{array}{l}\text { Most frequent response: } \\
\text { More than } 3 \text { years - } 76.7 \%\end{array}$ \\
\hline Log in pattern & $\begin{array}{c}\text { Most frequent response: } \\
\text { Several times a day }-58.6 \%\end{array}$ & $\begin{array}{c}\text { Most frequent response: } \\
\text { Several times a day }-48.7 \%\end{array}$ & $\begin{array}{c}\text { Most frequent response: } \\
\text { Several times a day }-84.9 \%\end{array}$ \\
\hline $\begin{array}{l}\text { Time spent per login } \\
\text { session }\end{array}$ & $\begin{array}{l}\text { Most frequent response: } 5- \\
15 \text { minutes / session }-32.2 \%\end{array}$ & $\begin{array}{l}\text { Most frequent response: } 5- \\
15 \text { minutes / session }-43.4 \%\end{array}$ & $\begin{array}{l}\text { Most frequent response: } 5- \\
15 \text { minutes / session }-31.5 \%\end{array}$ \\
\hline Engagers & Mean: -0.09 & Mean: -0.0 & Mean: 0.12 \\
\hline $\begin{array}{l}\text { Expressers and } \\
\text { Informers }\end{array}$ & Mean: -0.23 & Mean: 0.15 & Mean: 0.12 \\
\hline Networkers & Mean: -0.14 & Mean: -0.05 & Mean: 0.23 \\
\hline $\begin{array}{l}\text { Watchers and } \\
\text { Listeners }\end{array}$ & Mean: -0.13 & Mean: -0.14 & Mean: 0.30 \\
\hline $\begin{array}{l}\text { Trust in information } \\
\text { from personal } \\
\text { sources }\end{array}$ & Mean: -0.27 & Mean: 0.18 & Mean: 0.14 \\
\hline $\begin{array}{l}\text { Trust in information } \\
\text { from foreign sources }\end{array}$ & Mean: -0.08 & Mean: 0.03 & Mean: 0.06 \\
\hline Concern for privacy & Mean: 0.14 & Mean: -0.14 & Mean: -0.02 \\
\hline $\begin{array}{l}\text { Importance of social } \\
\text { media }\end{array}$ & Mean: -0.29 & Mean: -0.08 & Mean: -0.31 \\
\hline $\begin{array}{l}\text { Positive reactions to } \\
\text { online ads }\end{array}$ & Mean: 0.64 & Mean: -0.44 & Mean: - 0.31 \\
\hline
\end{tabular}

The first cluster formed consists of $36.9 \%$ of the total respondents who do not really engage in social media activities, and have a negative reaction towards networking activities, expressing themselves or being a spectator online, perhaps due to their high level of privacy concern. Also, they have social media profiles for more than 3 years, they seem to log in several times a day and just browse around social media websites for 5 to 15 minutes. However, they have a positive outlook on online advertising and have frequently clicked on such advertisements with the intent to purchase or find out more information.

The students forming the second segment are Expressers and Informers on social media websites, who have been using for an average of two to three years, several times a day, for 5 to 15 minutes. They do not worry about confidentiality issues and they trust mostly their personal sources of information, such as friends and family in an online environment. The $32.2 \%$ of the total sample do not appreciate the intrusive online advertisements; however, they have clicked on profile targeted ads a few times.

The third cluster comprises the respondents who get involved in all sorts of social media activities, as they can be classified as Engagers, Expressers and Informers, Networkers, Watchers and Listeners. Similarly as the respondents from the previous clusters, they are using social media for more than 3 years and tend to log in several times a day, for an average of $5-15$ minutes per session. Also, even though these respondents do not have a favorable perception regarding online advertising, they seem to have clicked on social media ads.

\subsection{Automatic Linear Modeling}

Furthermore, a SPSS specific procedure was used, namely Automatic Linear Modeling (ALM), in order to forecast and model a continuous target variable based on linear relationships between the target variable and its designated predictors. 8 continuous predictors and 4 categorical predictors were chosen in order to observe the impact on the target variable, namely, in this case, the positive reactions to online ads (Figure 1). 


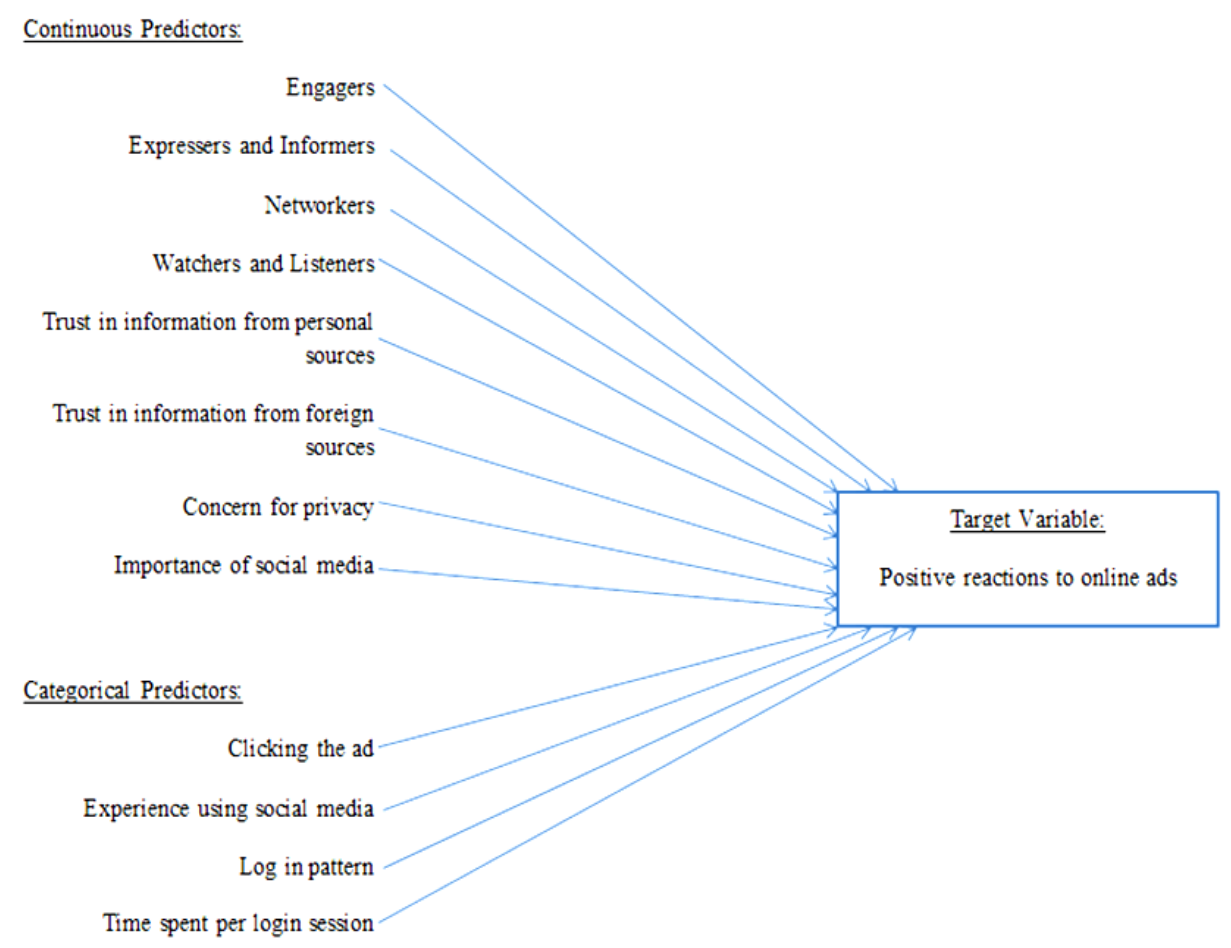

Figure 1. Concepts' relationship tested using automatic linear modeling

The model selection method used was Forward Stepwise, which starts with no effects and then adds and removes them at each step, based on the Information Criterion (AICC). Also, the preparation of the data was automatic. The accuracy value is $51 \%$ and it represents the adjusted $\mathrm{R}^{2}$ multiplied by 100 .

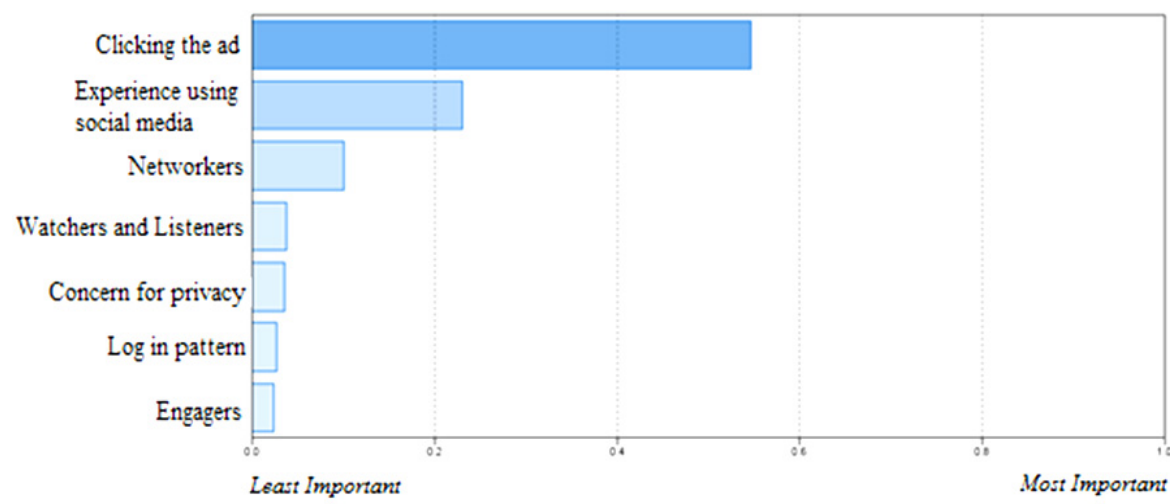

Figure 2. Predictor importance for the target variable in the automatic linear modeling procedure

Figure 2 shows the predictors in the final model and their assigned importance by the Automatic Linear Modeling procedure. The values are normalized so that the importance values sum one. The importance of a predictor represents the residual sum of squares with the predictor removed from the model (IBM SPSS, 2011). Hence, even though we included twelve predictors in order to study the target variable of positive reactions to social media advertising, the ALM procedure considered only seven variables: Clicking the ad, Experience using social media, Networkers, Watchers and Listeners, Concern for privacy, Log in pattern, Engagers. 


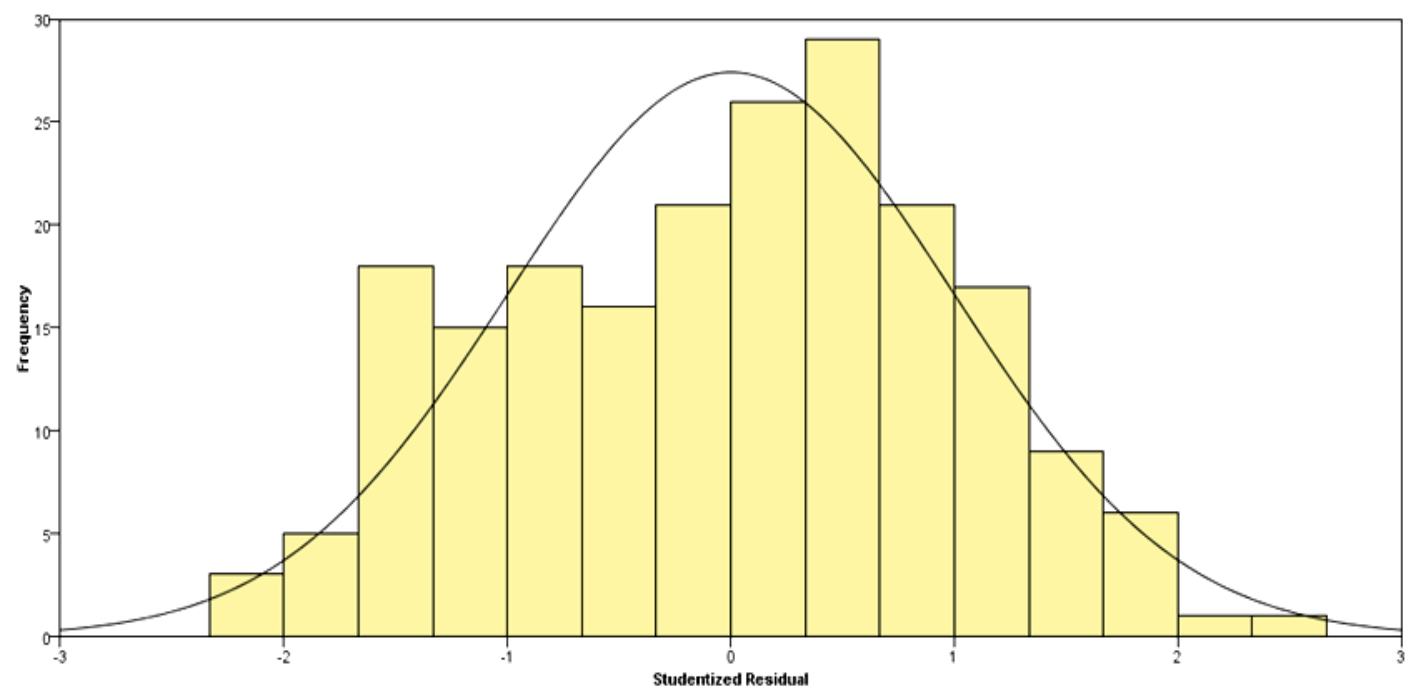

Figure 3. Studentized residuals for automatic linear modeling procedure

Figure 3 displays the histogram of Studentized residuals which compares the distribution of the residuals to a normal distribution.

Table 6. Analysis of variance for the proposed model

\begin{tabular}{lcccccc}
\hline Source & Sum of Squares & df & Mean Square & F & Sig. & Importance \\
\hline Overall model & 93.970 & 8 & 11.746 & 27.701 & .000 & \\
Clicking the ad & 45.125 & 2 & 22.563 & 53.208 & .000 & 0.547 \\
Experience using social media & 18.975 & 1 & 18.975 & 44.747 & .000 & 0.230 \\
Networkers & 8.2885 & 1 & 8.285 & 19.539 & .000 & 0.100 \\
Watchers and Listeners & 3.115 & 1 & 3.115 & 7.347 & .007 & 0.038 \\
Concern for privacy & 2.902 & 1 & 2.902 & 6.844 & .010 & 0.035 \\
Log in pattern & 2.177 & 1 & 2.177 & 5.135 & .025 & 0.026 \\
Engagers & 1.937 & 1 & 1.937 & 4.569 & .034 & 0.023 \\
Residual & 83.536 & & 0.424 & & & \\
\hline
\end{tabular}

The analysis of variance table presents information about the whole model, by examining how the independent variables interact with each other and what effects these interactions have on the dependent variable. Table 6 presents only the variables that are statistically significant according to the $\mathrm{F}$ test and does not include some predicting variables that would be considered to be insignificant according to this calculated statistic. In the information criterion, the Automatic Linear Modeling procedure used reduction in order to determine which predictors to add and which ones to eliminate from the final model, in order to increase the model's overall significance.

Regarding the seven variables (Clicking the ad, Experience using social media, Networkers, Watchers and Listeners, Concern for privacy, Log in pattern, Engagers) included in the modeling procedure, we can conclude that there is significant interaction between them and the target variable that studies the respondents' positive reactions towards ads displayed on social media websites. 


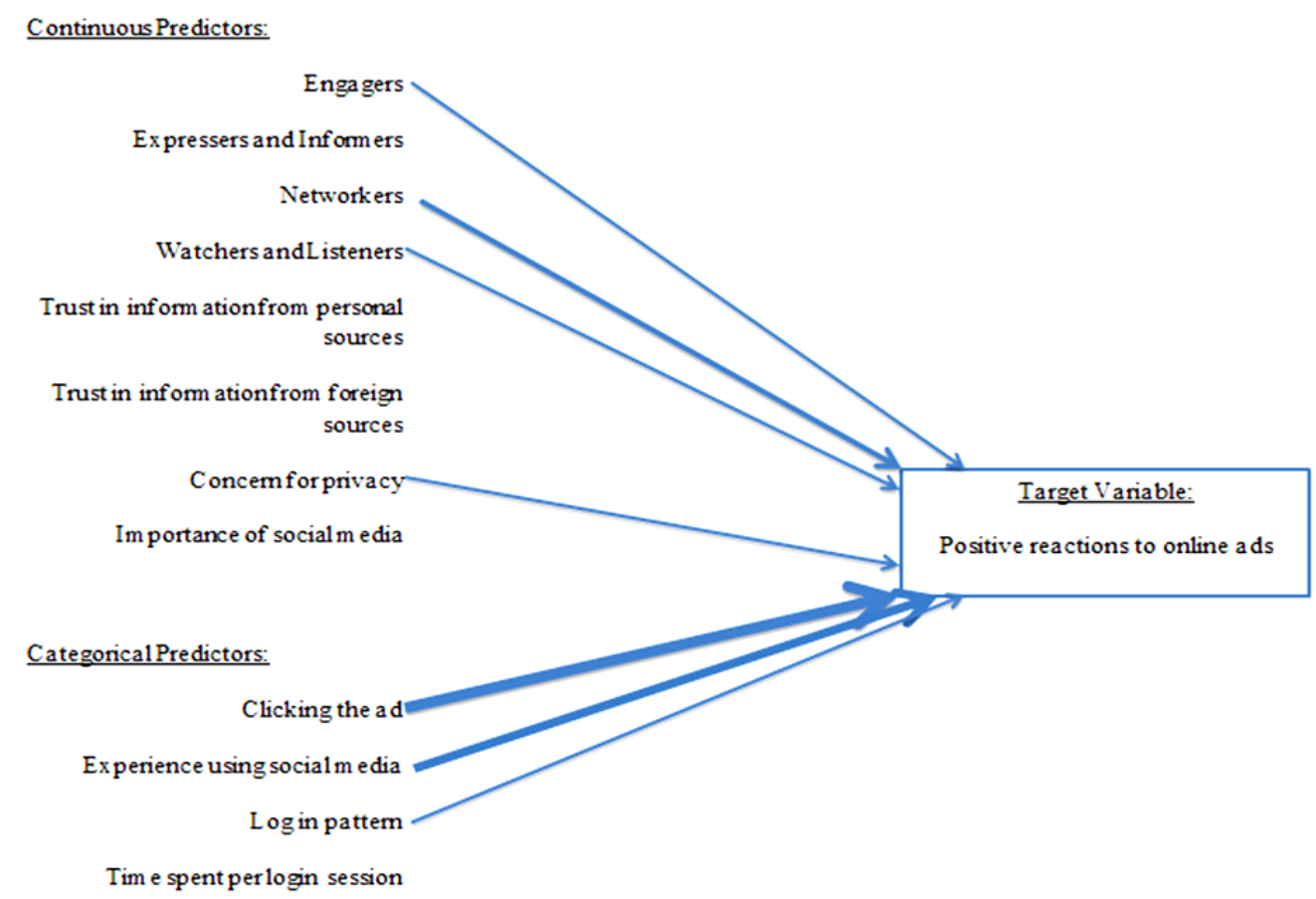

Figure 4. Effects exhibited for the proposed model in studying the target variable

Figure 4 represents the ANOVA table only in a graphic display. The predictor variables are ranked according to their assigned importance while the thickness of each connecting line represents the statistical significance of that particular effect on the positive reactions to ads, as a target variable.

Table 7 displays the estimates for parameters included in the overall model and their individual effects on the target variable (positive reactions to online ads). The column titled 'Coefficient' emphasizes the relationship each predictor has to the model's target variable. Moreover, the effects that are categorical predictors have multiple associated coefficients; one for each category except the category corresponding to the redundant parameter.

Table 7. Coefficients determined for the influential predictors for the target variable

\begin{tabular}{|c|c|c|c|c|c|c|c|}
\hline \multirow{2}{*}{ Model term } & \multirow{2}{*}{ Coefficient } & \multirow{2}{*}{$\begin{array}{l}\text { Std. } \\
\text { Error }\end{array}$} & \multirow{2}{*}{$\mathrm{t}$} & \multirow{2}{*}{ Sig. } & \multicolumn{2}{|c|}{ 95\% Confidence Interval } & \multirow{2}{*}{ Importance } \\
\hline & & & & & Lower & Upper & \\
\hline Intercept & 0.794 & 0.083 & 9.605 & .000 & 0.631 & 0.957 & \\
\hline Clicking the ad - Often & 1.406 & 0.159 & -8.865 & .000 & -1.718 & -1.093 & 0.547 \\
\hline Clicking the ad - A few times & -0.854 & 0.101 & -8.468 & .000 & -1.053 & -0.655 & 0.547 \\
\hline Clicking the ad - Never & $0^{\mathrm{a}}$ & & & & & & 0.547 \\
\hline $\begin{array}{l}\text { Experience using social } \\
\text { media - More than } 3 \text { years }\end{array}$ & 0.880 & 0.132 & -6.689 & .000 & -1.140 & -0.621 & 0.230 \\
\hline $\begin{array}{l}\text { Experience using social } \\
\text { media }-2-3 \text { years }\end{array}$ & $0^{\mathrm{a}}$ & 0.049 & & & & & 0.230 \\
\hline Networkers & -0.215 & 0.047 & -4.420 & .000 & -0.312 & -0.119 & 0.100 \\
\hline Watchers and Listeners & 0.127 & 0.049 & 2.711 & .007 & -.035 & 0.219 & 0.038 \\
\hline Concern for privacy & 0.128 & 0.147 & 2.616 & .010 & 0.032 & 0.225 & 0.035 \\
\hline $\begin{array}{l}\text { Log in pattern - Several times } \\
\text { a day }\end{array}$ & -0.333 & & -2.266 & .025 & -0.622 & -0.043 & 0.026 \\
\hline Log in pattern - Once a week & $0^{\mathrm{a}}$ & 0.046 & & & & & 0.026 \\
\hline Engagers & -0.999 & & -2.138 & .034 & -0.191 & -0.008 & 0.023 \\
\hline
\end{tabular}

${ }^{\mathrm{a}}$ This coefficient is set to zero because it is redundant. 
The coefficients show the relationship each predictor has with the target variable. Most notably, the students who actually often click on social media advertisements have a positive reaction to such marketing instruments. The model exhibits watchers and listeners who have a long experience with social networking sites, even though they have privacy issues.

\section{Discussion}

\subsection{Theoretical Contribution}

Nowadays, the analysis of consumer behavior is central for marketing success, especially since most potential consumers are using the internet and different online socializing tools. The online audience is a booming market worldwide, however giving its globalized nature a level of segmentation is needed cross-culturally. Regarding the academic implications, our results contribute to the study of the field of Internet marketing.

The conclusions obtained from our research have important implications for the academic research, derived principally from the analysis of four new types of social media consumers, namely Engagers, Expressers and Informers, Networkers, and Watchers and Listeners. We used this new classification, other newly formed variables (Positive reactions to online ads, Trust in information from personal sources, Trust in information from foreign sources), continuous variables (Concern for privacy, Importance of social media), and categorical variables (Experience using social media, Clicking the ad, Log in pattern, Time spent per login session) to achieve a segmentation of social media users and observe different patterns which could be targeted to improve the effectiveness and efficiency of online marketing activities. Therefore, this research presents new ways to classify online consumers, which served as a basis for psychographic segmentation, based on respondents' activities on different online platforms.

Also, this study contributes to the existing knowledge of customer behavior in an online environment, in general, and on social media websites, in particular, by providing insight through an examination of seven influential variables on developing positive reactions to online advertisements.

\subsection{Implications for Managers}

Today, any marketer or business owner understands the importance of internet marketing. Marketing a business on the web implies leveraging social media to create a lot of buzz in relation to a brand. Social media platforms offer immense possibilities for fostering relationships with consumers in an online environment. This study suggests different approaches for online marketers and managers looking to invest in advertising on social networking sites and hence improve their ads' performance regarding clicking the advert and generating positive reactions towards it. One approach implies understanding the sources of trust in online information provided by sources social media users may or may not know, and how their concern for privacy influences their reactions to online advertising.

Managers should be aware of the importance of social media sites in influencing online shopping by identifying and targeting different types of customers and taking initiatives to recognize and highlight customer interests.

In order to be successful in social media marketing, companies need to create a buyer persona and then develop and constantly adjust the online marketing strategy according to the interests of customers for long-term success. Figuring out what goes best for which particular audience leads to success. Regarding these aspects, companies can use online reputation systems in order to provide the right online incentives to the right online customers (Dellarocas, 2010).

True customer engagement means commitment-focused, not transaction-focused. The companies that master this aspect are the ones that are truly successful. They undergo continuous online marketing research and must be sensitive to changes in consumer behavior patterns and to identify new areas of consumer values and interest.

\subsection{Limitations and Future Directions}

Limitations of this study include those commonly associated with online questionnaires, including unsystematic sampling procedures and low response rates. While representativeness can always be improved, for the present research great efforts have been made in order to have a higher response rate for the sample.

This research is subject to some limitations which may provide fruitful avenues for future research. Firstly, certain limitations arise from the choice of the sample and the measurement of the variables used. Regarding the sample choice, this study presented responses gathered from students of Lucian Blaga University of Sibiu, Romania. The respondents do not, therefore, reflect customer attitudes and behaviors related to social media users in other countries. Moreover, given the sample, the research did not include in its analysis demographic variables, such as sex, age, social class, and ethnicity. Therefore, this is another area in which the research could 
be improved and extended, perhaps using these demographic variables as mediation variables.

\section{References}

Akrimi, Y., \& Khemakhem, R. (2012). What Drive Consumers to Spread the Word in Social Media? Journal of Marketing Research \& Case Studies, 2012, 1-14. http://dx.doi.org/10.5171/2012.969979

Al Kailani, M., \& Kumar, R. (2011). Investigating Uncertainty Avoidance and Perceived Risk for Impacting Internet Buying: A Study in Three National Cultures. International Journal of Business and Management, 6(5), 76-92. http://dx.doi.org/10.5539/ijbm.v6n5p76

Brengman, M., Geuens, M., Weijters, B., Smith, S. M., \& Swinyard, W. R. (2005). Segmenting Internet shoppers based on their Web-usage-related lifestyle: a cross-cultural validation. Journal of Business Research, 58, 79-88. http://dx.doi.org/10.1016/S0148-2963(02)00476-9

Cronbach, L. J. (1970). Essentials of psychological testing. New York: Harper and Row.

Dellarocas, C. N. (2010). Designing Reputation Systems for the Social Web. Boston U. School of Management Research Paper No. 2010-18. http://dx.doi.org/10.2139/ssrn.1624697

Dumitrescu, L., Stanciu, O., Tichindelean, M., \& Vinerean, S. (2012). Researching The Students Cognitive Space - A Relevant Phase in the Holistic Approach of the Higher Education Institutions Management. Far East Journal of Psychology and Business, 7(3), 26-36.

Dumitrescu, L., Tichindelean, M., \&Vinerean, S. (2012). Discovering social media behavior patterns in order to improve marketing strategy in the current chaotic environment. Revista Economica 6-64/ International Economic Conference - IECS 2012 (19th ed., pp. 24-35), Sibiu, Romania.

Field, A. (2005). Discovering Statistics using SPSS (2nd ed.). London: Sage Publications.

Hagel, J., \& Armstrong, A. G. (1997). Net gain: Expanding markets through virtual communities. Boston, MA: Harvard Business School Press.

Hanna, R., Rohm, A., \& Crittenden, V. L. (2011). We're all connected: The power of the social media ecosystem. Business Horizons, 54, 265-273. http://dx.doi.org/10.1016/j.bushor.2011.01.007

IBM SPSS. (2011). IBM SPSS Statistics for Windows, Version 20.0. Armonk, NY: IBM Corp.

Kaplan, A. M., \& Haenlein, M. (2010). Users of the world, unite! The challenges and opportunities of social media. Business Horizons, 53, 59-68. http://dx.doi.org/10.1016/j.bushor.2009.09.003

Laroche, M., Habibi, M. R., Richard, M. O., \& Sankaranarayanan, R. (2012). The effects of social media based brand communities on brand community markers, value creation practices, brand trust and brand loyalty. Computers in Human Behavior, 28, 1755-1767. http://dx.doi.org/10.1016/j.chb.2012.04.016

Mangold, W. G., \& Faulds, D. J. (2009). Social media: The new hybrid element of the promotion mix. Business Horizons, 52, 357-365. http://dx.doi.org/10.1016/j.bushor.2009.03.002

McDonald, W. J. (1996). Interact customer segments: an international perspective. In: Droge C, Calantone R, editors. Enhancing knowledge development in marketing (pp. 338-44). Chicago (IL): American Marketing Association.

Mersey, R. D., Malthouse, E. C., \& Calder, B. J. (2010). Engagement with Online Media. Journal of Media Business Studies, 7(2), 39-56.

Nunnally, J. C. (1978). Psychometric testing. New York: McGraw Hill.

Peterson, R. A., Balasubramanian, S., \& Bronnenberg, B. J. (1997). Exploring the Implications of the Internet for

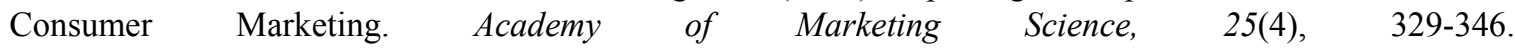
http://dx.doi.org/10.1177/0092070397254005

Ross, C., Orr, E. S., Sisic, M., Arseneault, J. M., Simmering, M. G., \& Orr, R. R. (2009). Personality and motivations associated with Facebook use. Computers in Human Behavior, 25, 578-586. http://dx.doi.org/10.1016/j.chb.2008.12.024

Trusov, M., Bucklin, R. E., \& Pauwels, K. (2009). Effects of Word-of-Mouth Versus Traditional Marketing: Findings from an Internet Social Networking Site. Journal of Marketing, 73, 90-102. http://dx.doi.org/10.1509/jmkg.73.5.90

Vellido, A, Lisboa, P. J. G., \& Meehan K. (1999). Segmentation of the on-line shopping market using neural networks. Expert Systems with Applications, 17, 303-14. http://dx.doi.org/10.1016/S0957-4174(99)00042-1 
Ward, S. (1974). Consumer Socialization. Journal of Consumer Research, 1(2), 1-14. http://dx.doi.org/10.1086/208584

Williams, L., \& Cothrell, J. (2000). Four smart ways to run online communities. Sloan Management Review, 41, 81-91.

Williams, T., \& Williams, R. (2008). Adopting social media: Are we leaders, managers or followers? Communication World, 25(4), 34-37.

\section{Copyrights}

Copyright for this article is retained by the author(s), with first publication rights granted to the journal.

This is an open-access article distributed under the terms and conditions of the Creative Commons Attribution license (http://creativecommons.org/licenses/by/3.0/). 